\title{
Three Different Cases of User Instructions for E-Learning Courses
}

\author{
Cătălin Popescu and Irina Rădulescu
}

University of Petroleum and Gas, Ploiesti, Romania

\begin{abstract}
The paper presents the structure of the learning material for the interactive course "International commerce". The whole learning material is described through its six components: learning content, evaluation tests, laboratory works, bibliography, webography, and term glossary. The authors present some possibilities of using an interactive course by adding three précised study cases. They are starting with a beginner student, supervised by his tutor, going on to checking the basic notions in a certain area and acquiring knowledge and, finally, to completing only some specific knowledge by the advanced students.
\end{abstract}

Key words: eLearning course, evaluation tests, strategies, module of content

\section{Introduction}

The dynamic evolution of Information Technologies and of the Internet has lead to the change of classical learning system in a modern one which offers several opportunities to all people. It has appeared the long distance learning which is very flexible and comfortable.

In this respect, many authors have tried to identify and discover several tools, modalities and technologies to develop elearning strategies.

Also, the importance of e-learning courses was emphasized by the European Commission which has launched the eLearning Action Plan in March 2001 and has defined the concept of e-learning as "the use of new multimedia technologies and the Internet to improve the quality of learning by facilitating access to resources and services as well as remote exchanges and collaboration".

If we look on different approaches concern e-learning fundamentals we discover varied definitions, but a good point of view stated that: "E-learning represents the delivery of formal and informal learning and Copyright (C) 2010 Cătălin Popescu and Irina Rădulescu This is an open access article distributed under the Creative Commons Attribution License unported 3.0, which permits unrestricted use, distribution, and reproduction in any medium, provided that original work is properly cited. Contact author: Cătălin Popescu: e-mail: cpopescu@upg-ploiesti.ro training activities, processes, communities and events via the help of all electronic media like Internet, intranet, extranet, $C D$ ROM, video tape, DVD, TV, cell phones, personal organisers etc.".

In his works, Pierfranco Ravotto identifies two types of e-learning:

- Individual, where there is no peer are two scenarios here: selflearning and supported selflearning; offer reciprocical support; the author identifies another two scenarios: virtual class and online collaborative learning.

Some advisors of University of Bristol have described the steps of e-learning:

- Need;

- Pedagogy;

- Resources;

- Creation;

- Evaluate.

M. Ramshirish and P. Singh have developed the necessary tools and technology for elearning courses such as: blogging tools, group and trainees are alone; there

- Group, where participants can 
collaboration tools, content converters, content management systems, course authoring tools, help authoring tools, learning management systems and website authoring tools. G. Piccoli shows the advantages of e-learning over traditional face-to-face education (time, material resources etc.) and Cem Işik describes the components of e-learning environment: the lecture room, the meeting rooms, the library, social interaction, additional system features. In order to develop the pedagogical content, eLearning trainers usually have specialised software products, called Management Systems for Learning Content (SMCI), which facilitate, up to a certain extent, the editing of the content and the drawing up of tests.

For some courses developed within the "Distance Learning" Department in the Oil and Gas University of Ploiesti, SMCI ToolBook II was used, developed by the company Asymetrix Learning Systems (Click2learn), as well as the development facilities regarding the learning content belonging to the Online Course system - a Web Based Training product.

\section{The structure of the learning material for the interactive course "International Commerce”. Case study.}

The interactive course "International Commerce", taught to the students in the Economic Science Faculty within Oil and Gas University of Ploiesti, was meant to be interactive and, currently, it can be found in the book entitled "International Commerce" published by the Publishing House of the Oil and Gas University of Ploiesti in 2008.

The whole interactive learning material is divided into:

- Learning content;

- Evaluation tests:

- Laboratory works;

- Bibliography, webography;

- Term glossary.

\subsection{The learning content}

The learning material is divided into eight parts:

Part I: Theories regarding international commerce, comprising the following modules:

Mercantilism (M1); The classical theories (M2); the neo-classical theories (M3); The contemporary theories (M4). This part is dedicated to looking over the main trends that dominated the economic thinking in various stages of its development, starting with the $16^{\text {th }}$ century.

Part II: From GATT to OMC - it includes the modules:

About GATT (M5); The principles of trading multilateralism (M6); The evolution of GATT towards WTO (M7); What has the future in store for us? (M8).This part is dedicated to describing the evolution of the International commerce in the period after Second World War.

Part III: World Trade Organisation (WTO) and its implications upon the international law - includes the modules: - About WTO and the role of the State in the International Law (M9); WTO and redefining sovereignty (M10); WTO and the principle of consensus (M11); WTO's contribution to the durability of the liberal principle (M12); ORD (M13); WTO and the role of multinational companies in the International Law (M15); WTO and the fragmentation of the International Law (M16); WTO and the human long-lasting development (M17); WTO and the human rights (M18); WTO and the building up of a new world administration (M19); WTO Law - the central element of a new Constitution of the world trade (M20); ORD - the main pillar of a good administration (M21).

This part is dedicated to the analysis of the WTO's contribution to the patrimony of the international law.

Part IV: The intercultural dimension of the international trade negotiations includes the modules:

Definition of culture (M22); Cultural variables (M23); Cultural dimensions (M24); The international trade culture and 
negotiations (M25); Principles regarding cultural disputes in the international trade negotiations (M26); Management modalities and the political culture of enterprises (M27).

This part is dedicated to reviewing a series of cultural variables and to defining the cultural dimensions in the opinion of some important researchers such as Geert Hofstede, Fons Trompenaars and Charles Hampden-Turner.

Part V: Export - a major challenge for enterprises includes the modules:

The business enterprise in the context of the development of information technology and communications (M28); Reasons related to the environment that favour the internationalization of activities (M29); Strategic reasons that favour internationalization (M30); What must be done to apply an appropriate strategy related to the expansion of enterprises on the international markets (M31); What opportunities and threats are there today for the Romanian enterprises referring to the international trade? (M32).

This part outlines the environment changes which have led to the internationalization of the activities of the enterprises in the last decades, simultaneously with the development of the information and communication technologies, as well as of the policy of the main international institutions (GATT, GATS, OMC, UNCTAD, ONU etc).

Part VI: Trade protectionism - theories and instruments comprises the following modules:

Trade protectionism - origins and current trends (M33); Protectionist tariff instruments (M34); Protectionist non-tariff instruments (M35); Policy of promotion and stimulation of exports (M36); Indicators for measuring the degree of integration in the international trade (M37).

This part is dedicated to trade protectionism.

Part VII: The national and international proportion of the internet trade phenomenon comprises the following modules:

Definition and evaluation of e-commerce (M38); E-commerce development in the world (M39); E-commerce strategy (M40); eBay phenomenon (M41); Aspects concerning the e-commerce in Romania (M42).

This part is destined to the analysis of the e-commerce phenomenon in the world.

Part VIIII: Case studies comprise the following modules:

Aspects concerning the development of ecommerce in France and Romania (M43); Local trade agreements and WTO rules (M44); The e-banking context: computerization of financial services (M45). Each of the eight parts mentioned above contain a general presentation which comprises main ideas, images, animations and the structure of each module. One can access the respective module by simply clicking the mouse on an adjoining button. We have to mention that using the same principles it was organized the teaching material for the interactive course called "Fundamentals of Management", which is dedicated to the students from Management specialization, first year.

\subsection{Seminar papers}

The role of the seminar papers is to offer the guiding teacher (tutor) a set of exercises and practical applications for each module mentioned in the structure above.

This set of exercises can also be used by a student who wishes to thoroughly study the subject matter and to check differently than by means of a test - his way of understanding the content of the subject matter.

\subsection{Bibliography and webography}

The bibliography helps the student to supplement his knowledge regarding the material studied. Any interactive course also contains basic bibliographical references, among which the references on the Internet (webography) play an 
essential role considering their being something new and the immediate possibility of the student to access them by means of his computer connected to the network.

\subsection{Term glossary}

Any specialty course generally contains a term glossary. The usefulness of the term glossary is unquestionable, considering the great number of terms pertaining to the multimedia area, but also to other areas, many of them being borrowed from the English language or other international languages, and taking into account the rapid development of the technical and organisational means which define the respective specialty domains.

\section{Strategies of using the interactive course "International Trade"}

Next we shall present, by means of a few concrete cases, the possibilities of using the interactive course "International commerce" which is currently developing within the Oil and Gas University of Ploiesti.

\subsection{The first case: a beginner student}

A first case would be that of a beginner student who wishes to study, for example, the theories that govern the international commerce.

In this respect, the student will access the Table of contents of the course, and then he will activate Part I, entitled "Theories regarding international commerce".

After getting through the course and learning the notions in the text, his knowledge will be evaluated. This will be carried out first by means of a selfevaluation done by the student himself, then by the complex evaluation done by his tutor, who chooses and applies the test modules that he considers to be appropriate and, depending on the result, the tutor may recommend to the student a supplementary bibliography.
The entire process is assisted by the Training Management System (TMS) by means of the computer and of the Internet. In figure 1 we present the functional modelling of this case, by means of the diagrams of the cases of UML 2 use.

\subsection{The second case: I would like to assess my knowledge and move on}

Another case is that of a student who has some knowledge about World Trade Organisation (WTO), for example, and wishes:

- to evaluate his knowledge in WTO;

- to complement his knowledge with some new information, for example about "Local trade agreements and WT0 rules" (see module M44).

In figure 2 we present the functional modelling of this case, by means of the diagrams of the cases of UML 2 use. The general module of content (TIC) will be activated, the contents will be gone through, Part II, "From GATT to WTO", will be chosen and the summary of this part will be read.

Self-evaluation will be carried through by doing the afferent tests. In addition to the tests, the revision questions and the summarising exercises will be done.

The results will be displayed and the learning process goes on either by checking further knowledge in the same way, or by accessing module M44 which, as shown above, contains the "Local trade agreements and WTO rules".

3.3. I would like to complete some specific knowledge in the area

The third case that we will examine is that of a student who wishes to complete some specific knowledge in a certain area, for example in international commerce culture and negotiations.

In figure 3 we present the functional modelling of this case, by means of the diagrams of the cases of UML 2 use.

After the general module of content (TIC) has been activated and the table of 
contents has been gone through, the student will choose Part IV, "The intercultural dimension of the international commerce negotiations", and ticks the modules he is interested in. He will go through the modules, he will complete his knowledge, going over the revision questions if necessary, and then he moves on to the self-evaluation tests in order to check the understanding of the notions he has acquired. According to the selfevaluation results, he will look through other modules within the same chapter or access other parts of the course in order to complete his knowledge in the area.
We specify that the entire content of the interactive course "International Commerce" is to be found in the paper with the same title, author Irina Radulescu, published by the Publishing House of the Oil and Gas University in 2008.

As while going through the material published as a book the automatic evaluation is not possible, the reader is requested to write down the answer to each test in the space especially designed to serve this purpose, according to the model in diagram 1.

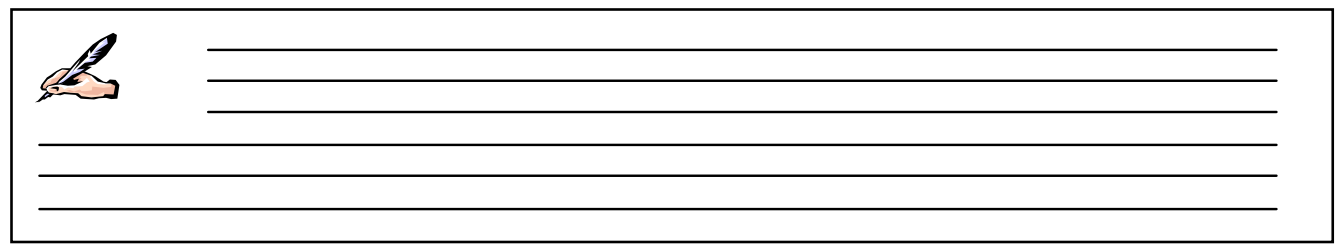

Diagram 1 Space for writing down the answer to the test 


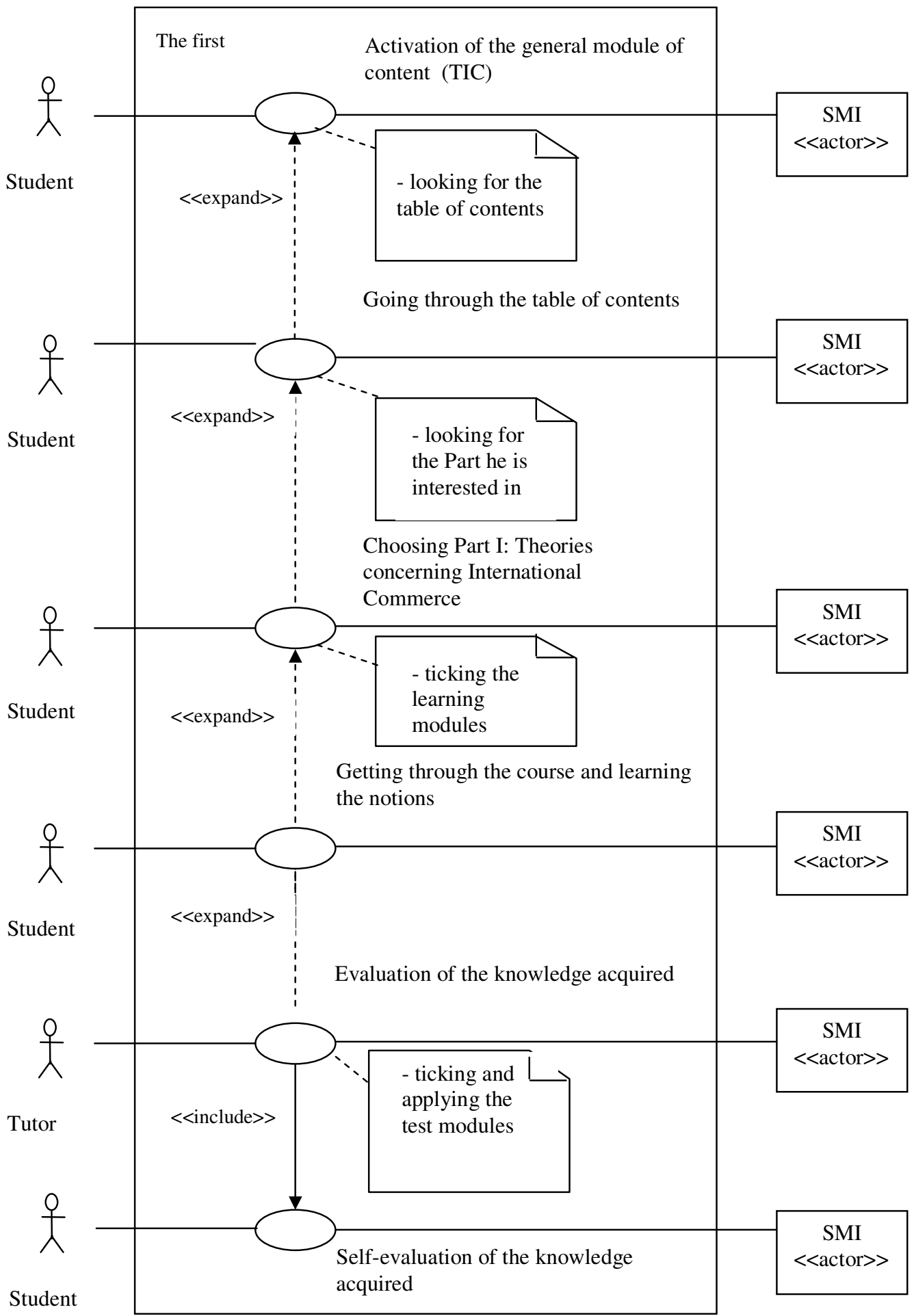

Fig. 1 The diagram of the cases of use for a beginner student TMS - Training Management System 


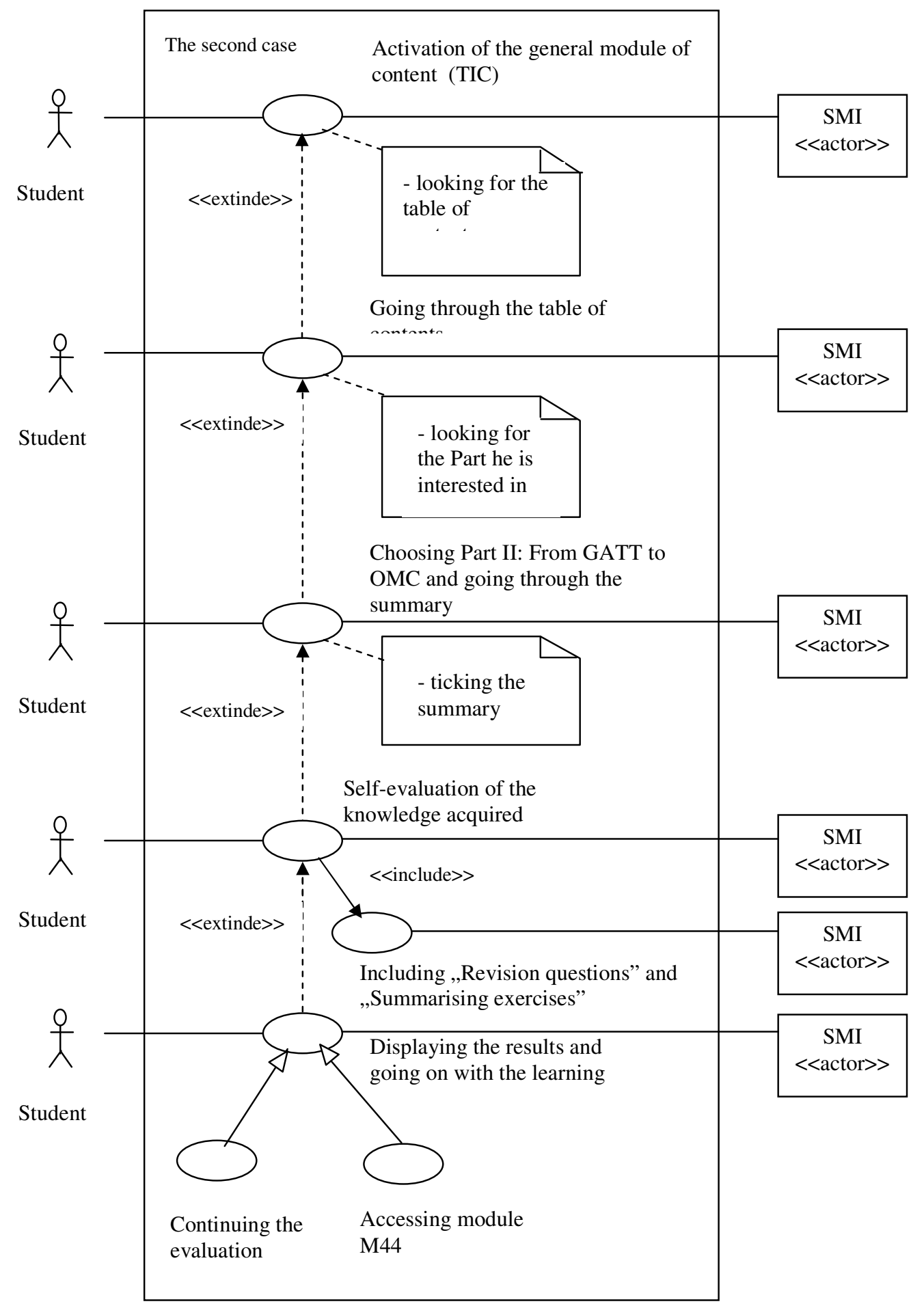

Fig. 2 The diagram of the cases of use for the student who wishes to assess his knowledge and move on 


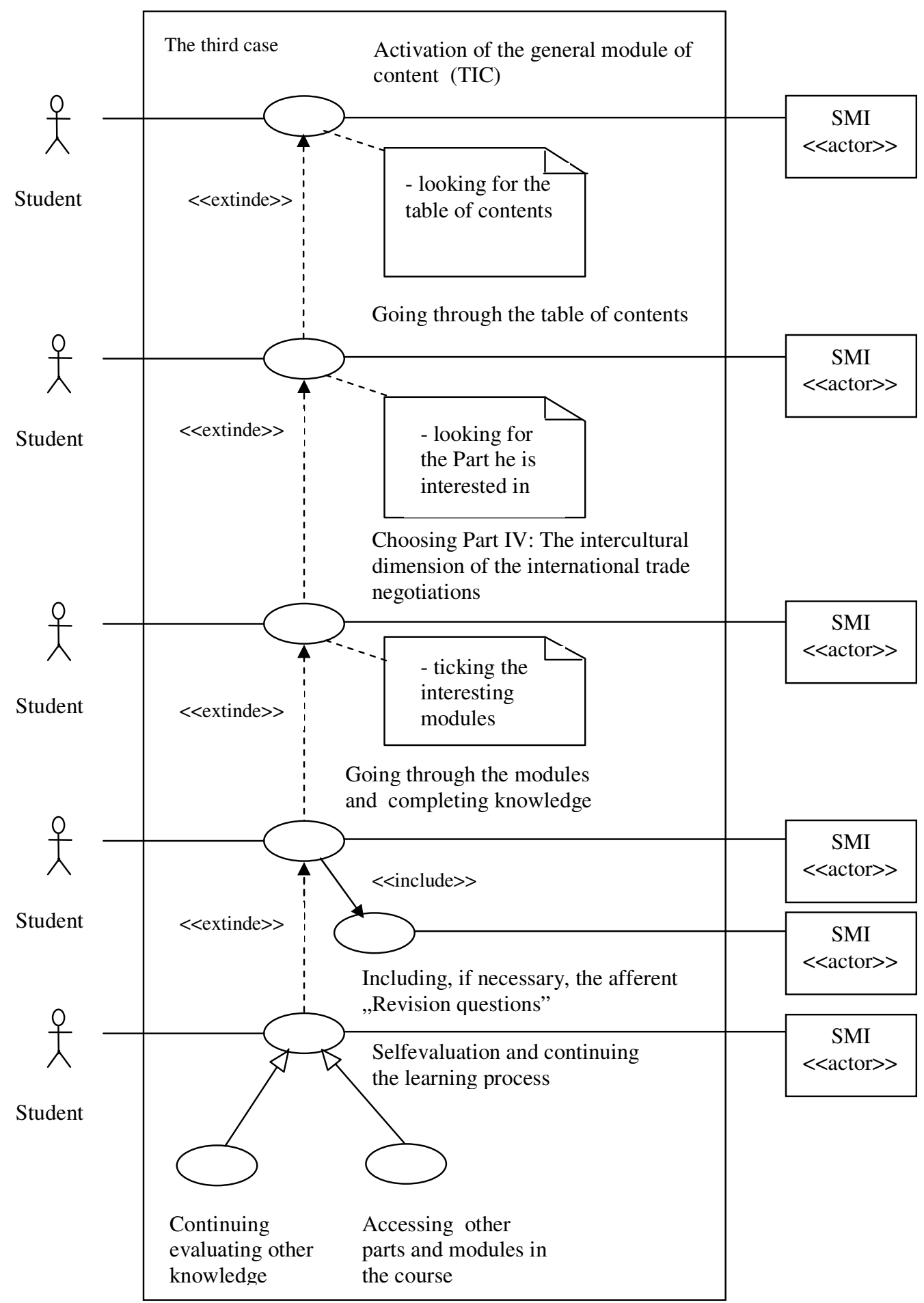

Fig. 3 The diagram of the cases of use for the student who wishes to complete some specific knowledge in the area 
In the same design stage we could mention another interactive course called "Fundamentals of Management". Some important parts of the course could be found in the book called: "Company's Management", author Cătălin Popescu, published by the Publishing House of the Oil and Gas University in 2003.

\section{Conclusions}

We have presented above the strategies of using the interactive course "International commerce", which is currently developing within the Oil and Gas University of Ploiesti.

The structure of the learning material for this course, presented above in paragraph 2 , has allowed the drawing up of varied strategies, starting from the acquiring of basic notions by a beginner student, supervised by his tutor, going on to checking the basic notions in a certain area and acquiring knowledge and, finally, to completing only some specific knowledge by the advanced students. All the strategies mentioned above were developed within the Oil and Gas University in Ploiesti in 2008 and are currently under implementation.

\section{References}

Antonescu, N.N, Dumitraşcu, L., Guțu, S., Meyer, A., Ulmanu, V., Lambrescu, I., Ioniță, L., Moise, G. (2003), eLearning, Publishing House of Ploiesti University.

Dumitraşcu, L., Dumitrescu, St., Moise, G., Ioniță, L., Dumitraşcu, D. (2003), Instructional software programs use in the Romanian high education system, Cyprus University, Nicosia, CBLIS.

Guțu, S. (2001), Tehnologiile informației şi comunicațiilor. Mijloace multimedia, Bucharest, Ed.Ilex.

Guțu, S., Dumitraşcu, L., Marcu, G., Ioniță, L., Dumbrăvescu, B. (2005), Analiza şi proiectarea orientată obiect a sistemelor informatice cu UML, Publishing House of Ploiesti University.

Işik, C. (2009), E-Learning in Life Long Education, College of Economic Studies, Prague-CZ-E-learning Conference, May 2009.

Mingasson, M. (2002), Le guide du elearning L'organisation apprenante, Éditions d'Organisation.

Piccoli, G., Ahmad, R., Ives, B., (2001), Webbased virtual learning environments: a research framework and a preliminary assessment of effectiveness in basic it skills training, MIS Quarterly 25(4)

Popescu, C. (2003), Managementul firmei, Editura Universității de Petrol-Gaze din Ploieşti.

Radulescu, I. (2008), Comert internațional, Editura Universității de Petrol-Gaze din Ploieşti.

Ramshirish, M. and Singh, P. (2006), Elearning: Tools and Technology, DRTC Conference on ICT for Digital Learning Environment, 11th-13th January, Bangalore

Ravotto, P., Developing e-learning lessons, ITSOS « Marie Curie »

European Commission, (2001), eLearning Action Plan, March, page 2.

5 Steps to e-learning, http://www.bristol.ac.uk/elan/5steps/5st eps.htm

http://www.leerbeleving.nl/wbts/1/histor y_of_elearning.html 